\title{
Internet communications in the information age: socio-cultural and environmental context
}

\author{
Olena Sidorkina ${ }^{1}$, Tetiana Poda $^{1}$, Oksana Skyba $^{1}$, Natalia Chenbai ${ }^{1}$, and Ivan Skyba ${ }^{1,{ }^{*}}$ \\ ${ }^{1}$ National Aviation University, 1, Liubomyra Huzara ave., Kyiv, Ukraine
}

\begin{abstract}
The article deals with specifics of Internet communications functioning in the information technology era. The emergence and development of Internet communications in human life promote the creation of virtual reality, which significantly changes the forms of relationships between people. Instead of personal meetings and direct communication, people get used to communicating in virtual space. It affects their professional activity, studying, personal life, leisure, etc. The latest forms of Internet communication not only open up to mankind the unique opportunities for a person's creative self-realization but also make a new socio-cultural reality. Therefore, it is necessary to study the peculiarities of the new forms of Internet communications' functioning and their impact on social development.
\end{abstract}

\section{Introduction}

At the beginning of the 21st century, the rapid development of science and technology ushered in a new civilization based on the information and computer technology and worldwide communication. In recent years, the latest technologies have gradually penetrated into all spheres of society: science, education, leisure culture, etc. They have become the basis for the emergence of new forms of virtual communication, increasingly replacing real communication. Officially, the Internet has emerged in the last century, but in recent decades, information technology has reached a level of development that is beginning to make a powerful influence on the progress of civilization processes. First of all, it concerns communication processes, because communication in a virtual environment, using Internet technologies, has its own peculiarities. Indeed, the old traditional forms of communication are partially preserved, but some of them are gradually fading into history, for example, telegrams are gradually replaced by SMS, and ordinary letters are push out by communication in the information network (Skype, various forums, etc.). There is a gradual modification of the traditional communication system, which contributes to the emergence of new forms of information and communication systems.

Thus, at one time, the emergence of abstract services and bibliographic techniques was necessitated by these means of communication. Then a person witnessed how the publication of the articles was modified into various types of more advanced information technology; typewriters and letters gave way to computers and e-mail. Some Western

\footnotetext{
*Corresponding author: Skibaip@gmail.com
} 
theorists, particularly D. Bell, E. Toffler, and M. Castells, noticed at the end of the last century that the growth of the role of theoretical scientific knowledge and information was determined by the characteristic features of the information society. Today, the appearance of new information and communication systems testifies to the growing importance of information in the functioning of public and state institutions and in the life of every society member.

V. Onopriienko pays attention in his researches on the peculiarities of communication processes in science. He analyzes different types and forms of scientists' communication (10 Onopriienko, 2008). In her work, A. Yefremova explores information interaction as a new form of communication and analyzes existing forms and types of Internet communications. The author also notes that communication in the virtual environment of the Internet technologies makes communication cross-border. This communication occurs through a kind of a discourse that has been formed in computer networks and creates a special communication type and communication norms (5 Yefremova, 2014). O. Biriukova dedicates her studies to the Internet network as a kind of electronic communication. The author deals with the problem of defining the general concept of Internet communication, its functions, features, and types in modern society, which introduce new forms of dialogue and communication into the society and its every sphere. The scientist also draws her attention to the ways of Internet communication and its linguistic features (1 Biriukova, 2014).

The renowned French scientist J. Balandier notes that there are three forces ruling in the modern world, namely information, technology, and communication. "A man of the late twentieth century is like in an invisible cocoon created by the provided networks; at the same time, the boundaries, traits, and noises of the world are being effaced... Communication domination is progressing, it is on the way to becoming the first truly universal imperial realization. The everyday and scientific knowledge seems to be reconciled to a fact that communication dominates today" (6 Zheltov, 2008). Along with the positive results of the introduction of new means of interpersonal communication, there are also phenomena of concern like "fake" content or "trolling" etc. That is, the Internet content and media are becoming more powerful means not only of broadcasting diverse information but also of the purposeful formation of virtual space as well as modeling of human behavior and manipulation of its consciousness (15 Sidorkina, 2017).

All the above suggest we rethink the role and nature of the communicative component in contemporary political space as well as anticipate and justify the prospects of a "communicative turn" in world politics. This makes it possible to minimize the effects of globalization, inherent in instability and fragmentation of the world community development, to improve the mechanism of political communication, and promote confidence among the subjects of the world political process. When examining the field of political communication, it is necessary to take into account the heterogeneity of the cultural and linguistic styles in different states participating in political discourse. It is also important to remember that the discourse takes place in the postmodern paradigm (11 Poda, 2012). The increased importance and impact of communication on public political life can be explained by the rise in the professionalization of politics. The emergence of professional politicians has led to dramatic changes in the governmental structure, as the requirements for political subjects have changed significantly. One of such a requirement for politicians is the ability to convince the interlocutor by verbal means. Thus, politicians began to operate by not only such tools as a gun and a pen but also a word. A professional politician in the modern world must exert influence through many factors, with a communicative one becoming the most important.

In the era of information technology, scientists have not ignored the peculiarities of social networking, such as Facebook, Vkontakte, etc. Thus, in his work, J. Montepare 
draws attention to the different types of non-verbal signals used by users in information exchange (20 Montepare, 2014). So, as we can see, today there is a gradual penetration of new technologies, particularly Internet communication, in different spheres of society such as science, education, professional activity, leisure, etc. It leads to the formation of the "social presence" concept (21 Yildiz, 2009; 46) in communication between people and the formation of a new socio-cultural space.

\section{The objective and task}

The emergence and development of innovative communication forms in human life cause the creation of virtual reality, which significantly changes the forms of relationships between people, entails the person's alienation from real-life and can lead to the complete replacement of real things with images. Instead of personal meetings and face-to-face communication, people get used to communicating in virtual space. It affects both their personal lives and work. The latest forms of Internet communication not only open up to mankind the unique opportunities for a person's creative self-realization but also make a new socio-cultural reality affecting all spheres of social life. Therefore, it is necessary to study the peculiarities of the new forms of Internet communications' functioning and their impact on society.

\section{Research methods}

The theoretical and methodological basis of this research is the general scientific and special methods and approaches by which the dynamics of changes in the communication system under the conditions of the information society will be investigated. One such approach is a systematic approach. Its application is caused by the complexity and variability of the object of investigation and will allow tracing and taking into account such important aspects of new forms of Internet communications as anonymity of communicators, the distance of communication, the access speed of information, high level of feedback and more. The methodological role of the systematic approach is that it allows identifying and analyzing both the individual components and peculiarities of the communication system functioning, and provides the study of the object as a single, specific system. It is not superfluous to apply a synergistic approach, as some researchers (1 Biriukova, 2014) note that new forms of electronic communications are evolving according to a network model characterized by synergistic and dialogical aspects. Their main advantage is the openness to dialogue and the possibility of self-organization.

\section{Results}

Scientists distinguish the following types of Internet communication as the most common: (5 Yefremova, 2014):

1) A human - a computer. This type of communication allows you to receive information, regardless of the actual location of the source, as well as to send and store information on this computer. In this case, the Internet acts as a kind of information repository. A tablet or a smartphone can act as a receiver and transmitter.

2) A human - a human. In this type of communication, the user can communicate with any other user and perform all types of information transmission, e.g. via the text (e-mail), voice (Internet telephony) and images (video telephone, a conference or network communication). 
3) A human - humans. It is the traditional type of mass communication when information is sent to a large number of people at the same time. The Internet globalizes and reduces the cost of this communication type. As an information repository, the Internet allows us to create archives that can be used by a large number of people.

4) Humans - a human. This type of communication allows collecting and organizing information from many people.

5) Humans - humans. It is a simultaneous communication of a large number of people.

Let us trace the place of every communication type in each sphere of society. The first and second types of communication are most commonly used in science and education. According to the history of science, scientific journals once used to be one of the important sources of information and the most successful means of scientific communication and served as the primary source for publishing the results of scientific research and exchange of views. That is why the emergence of a new form of a scientific journal (an electronic one) has led to a number of changes in the system of scientific communications. The advantages of the e-journal include: it is quicker to prepare and distribute the publications (the article may be available sometimes several months earlier than it appears in the printed version of the journal); it is available on the Internet at any time from any workplace (that is, scientists do not need to spend their precious time in libraries); it is possible to "download" electronic text for further work (copying, notes, abstract, etc.) and so on.

The rapid development of e-journals and their undisputed advantages are predicted to terminate traditional (paper) journals in the near future. The new forms of Internet communication have also led to further discussions in the professional community around models of scientific communication in general. They also suggested alternative models of scientific communication. "The Open Access" (two components of this initiative are the Open-access Archive or the Institutional Repository and the Open-access Journals) are currently the most well-known. (17 Yaroshenko, 2006: 150). According to T. Yaroshenko, the Open Access Initiative "was launched" in 2001 as an alternative model of scientific communication, providing free access to qualitative (peer-reviewed) scientific literature on the public Internet with the right to read, download, copy, distribute, print, and make reference to full-text articles (17 Yaroshenko, 2006: pp. 150-151). Such scientific digital collections and archives make it possible to quickly prepare e-books and educational materials, facilitate the search for required texts, contribute to the integration into global scientific databases, thereby reducing the degree of scientific isolation and creating new opportunities for collaborative research projects.

Moreover, the new forms of Internet communication bring temporary groups of scientists together not only from different countries but from different continents in order to solve the radically new problems of modern science. At the same time, their communication is not always immediate. It means that each scientist can solve a problem, communicating through social networks. But the complex, global scientific problems are solved by teams of scientists who are directly interconnected and work side by side. For example, it was while investigating the Big Bang theory through the use of the Hadron Collider built jointly not only by scientists but also by software engineers and specialists from other fields of science and manufacture (4 Drotianko, 2018; 11).

Of course, the Internet, electronic libraries, repositories, etc. are new ways of storing, processing and disseminating information, they have some advantages, as well as disadvantages. The text is in a new virtual dimension. If the printed text existed on paper, it was read and discussed, while the "screen culture" only implies the information circulation. There is an automatic deconstruction of the text. Its integrity and archaism give way to countless repeated use of individual semantic elements" (3 Vakulych, 2013). This is primarily due to the appearance of hypertext on various web pages, where the text can be viewed not in a linear sequence, but as a system of possible indicated transitions 
("hyperlinks"). In this case, the material can be read non-linearly, transiting from one text to many others. Sometimes the author of such texts may be unknown or act as a virtual personality. This is especially important for the development of education as one of the most important social spheres, where the influence of Internet communications is particularly significant today.

The modern education system is increasingly using the latest educational technologies to organize distance learning and obtain continuing education. However, the use of hypertext to present material qualitatively alters the cultural content of the text submitted. After all, the Internet "is intolerant" to the book organization of the text, where the text fragments follow one after the other, like wagons clamped in a single train, according to the author's intention. Integrated into the World Wide Web, the text has hypertext fields. It has new random links created by "someone". It largely loses the author and the semantic completeness. The text turns into a "draft" (3 Vakulych, 2013). It arises the logical question: how good the higher education will be, if only "drafts" are used, in addition, the author of which is unknown. In such a model of education, the teacher's functions are tried to be reduced only to the preparation of hypertext materials. At the same time, the value of live dialogue and direct communication in the "student-student" system is underestimated. But not everything can be conveyed through virtual communication, because a person lives in the real world and in a real socio-cultural space.

Today, when the latest information and communication technologies provide access to information, there are some difficulties in using Internet communications in education and science, as was mentioned earlier in the previous research (13 Skyba, 2018). These include, first of all, the availability of technical support in educational and scientific institutions (computers, modems, etc.); the almost complete lack of a methodological base for the use of the latest technologies in education; the need for the creation of electronic libraries and more. With regard to the last three types of Internet communication (a human - humans; humans - a human; humans - humans), they are more characteristic of social networking.

\section{Discussion}

With regard to scientific communication and education, the successful creative interaction of scientists during their work largely depends today on the level of information culture (network etiquette, netiquette) of scientists, researchers, teachers and students and on their ability to use the latest information and communication technologies. In this case, information technologies act as an instrumental knowledge in the most general sense or "as an intellectual tool, a means used to achieve a certain purpose in the process of social activity (a practical or spiritual one) ..." (14 Skyba, 2018; 114). Let's consider the role of the various social networks functioning in social life like Facebook, Vkontakte, Odnoklassniki and more.

The web offers a variety of web pages containing information about people, their interests, hobbies, world news in politics, science, culture, etc., which then serve as a network community. Based on the analysis of these virtual network communities, we can draw some conclusions about factors that attract people, especially youngsters, to social networking. These factors include: gaining new social experience and, also, socializing in cyberspace; the dynamism of network space and active knowledge of the world; the use of technical innovations, game forms of interaction, as well as Internet technologies for information and communication (8 Konovalova, 2016; 93). That is, social networks are becoming a powerful tool to influence the formation of public opinion and the cultural life of people. Information circulating in certain groups of social networks gradually penetrates into the individual network space. Thus, it influences the consciousness and the individual communicators' thinking formation. Gradually, information influence on communication 
participants is becoming weaker. So, in order to maintain the "continuous effect of a wavelike network communication" (8 Konovalova, 2016; 93), a new information impulse is needed that is very often observed in a form of various "likes" and "reposts".

Table 1. The We Are Social agency and Hoot suite list the following numbers for worldwide network expansion as of 2018.

\begin{tabular}{|c|c|}
\hline Facebook & 27 billions \\
\hline Youtube & 15 billions \\
\hline Whatsapp & 13 billions \\
\hline $\mathrm{Fb}$ messenger & 13 billions \\
\hline Wechat & 980 millions \\
\hline QQ & 843 millions \\
\hline Instagram & 800 millions \\
\hline Tumblr & 794 millions \\
\hline Qzone & 568 millions \\
\hline Sinaweibo & 376 millions \\
\hline Twitter & 330 millions \\
\hline Baidutieba & 300 millions \\
\hline Skype & 300 millions \\
\hline Linkedin & 260 millions \\
\hline Viber & 260 millions \\
\hline Snapchat & 255 millions \\
\hline Reddit & 250 millions \\
\hline Line & 203 millions \\
\hline Pinterest & 200 millions \\
\hline YY & 117 millions \\
\hline Telegram & 100 millions \\
\hline Vkontakte & 97 millions \\
\hline BBM & 63 millions \\
\hline Kakaotalk & 49 millions \\
\hline
\end{tabular}

As shown in the table, 2017 was a very good year for Mark Zuckerberg and his team, as it has shown significant growth across all FacebookInc-owned platforms (7 Internet, 2018). Facebook's main site continues to dominate social media, increasing users by $15 \%$ year over year. At the beginning of 2018, there are about 2.17 profiles on the social network.

At the same time, the growth users' rate of Whats App and Facebook Messenger was twice as fast as the main Facebook platform in 2017. The number of users has been increased by $30 \%$ over the year. Having an approximately equal number of users, Whats App dominates geographically according to Similar Web and covers 128 countries, whereas Facebook Messenger gains the lead in 72 countries. The Facebook-owned messenger is not the most popular only in 25 countries. Despite the above figures, Instagram has bypassed all the Facebook apps in terms of growth in 2017 and increased the number of its users by one third (7 Internet, 2018). Of course, other agencies may provide other statistics that may differ from We Are Social's data. However, the increasing popularity of social networks in the world is an accomplished fact. 
The results of some surveys have confirmed that social networks are the most popular Internet resources. About $87 \%$ of those surveyed have their own profile on the network because they feel the need for communication; (70\%) are interested in watching videos, photos, and listening to music; about $30 \%$ of respondents chose participation in "interest groups" and "meeting new people". (9 Mediasphere, 2015). Numbers may slightly differ from other sources, but as we see, communication is one of the most common types of human activity in social networks, and the Internet is a universal means of communication.

Today, it has become possible to talk about the formation of the so-called "Internet subculture" (2 Boiarova, 2009), with its own language, ideology, internal hierarchy, defined rules and norms of communication, even formal and informal leaders, which form certain communities of communicators. People can be differently brought to the knowledge and common cultural values, but now this process is mainly done through information and communication technologies. The Internet is a very effective way of developing cultural heritage. Therefore, it should not be forgotten that its "application should be competent and appropriate" (16 Chenbai, 2018; 130), so as not to harm a person. And, given that the Internet promotes the process of symbolic exchange, where the individual selfunderstanding of a person is mediated by symbolic material from different sources, it is worth noting that the Internet acts as a cultural standardizer in intercultural communication through network etiquette, netiquette, and reveals cultural differences (18 Marcoccia, 2012; $353)$.

\section{Conclusions}

In the context of modern civilization development, the emergence of new Internet technologies is an important factor of socio-cultural changes. The Internet not only provides us with access to giant information repositories but also helps to organize, process and transmit information, as well as store the knowledge gained. The latest forms of Internet communication provide us with the means to create new knowledge that will be accessible to all communication participants. The advent of new forms of scientific communication (The Open Access, etc.) and creation of electronic libraries and repositories, made the distance learning and self-study possible, regardless of the location of the communicator. Internet communications also play a certain role in the preservation, development, and broadcasting of socio-cultural values. For example, even many museums arrange virtual viewing of their exhibits and collections.

The virtual communication created by the network forms its own subculture. It has its own norms, prohibitions, its own emotional atmosphere, etiquette and its own features unlike direct communication in real life. Internet communications create their own sociocultural space, becoming an integral part of all spheres of human life and replacing the process of real communication with the virtual one. The functioning of social networks today is important not only for organizing personal contacts and leisure but also for securing professional connections, education and more. Global transformations in the modern world define new research areas of communication in the international dimension, which is reflected in foreign concepts of global civilization, the information society doctrines, and theories of new information and communication network's impact on world politics.

It should also be noted that Internet communications continue to evolve, although the opportunities they offer are rather unevenly distributed. This indicates that the development of digital communications has not reached its maximum level. There are also transformations observed in the field of online consumption. It means that more and more Internet users get access to the network via mobile devices; the number of online purchases increases; and social networks are becoming more important in politics, business, 
education, etc. It is difficult to foresee the future, but Internet communications will obviously penetrate even deeper into our daily lives.

\section{References}

1. E.A. Biryukova, Yazyk. Slovesnost. Kultura 6, 75-98 (2014)

2. K.V. Boyarova, Internet yak zasib komunikacï̈ lyudej. Materialy IV Mezhdunarodnoi nauchno-prakticheskoi Internet-konferencii «Alyans nauk: uchenyj - uchenomu» (Dnepr, 2009)

3. N.R. Vakulich, Obrazovanie v sovremennom mire: sbornik nauchnyh. statei Izdadelstvo SGU 8, 21-28 (2013)

4. L.H. Drotianko, Visnyk Natsionalnoho aviatsiinoho universytetu. Seriia: Filosofiia. Kulturolohiia: Zbirnyk naukovykh prats 1(27), 9-13 (2018)

5. A.A. Efremova, Mezhdunarodnyj studencheskij nauchnyj vestnik 1 (2017) https://www.eduherald.ru/ru/article/view?id=16861

6. V.V. Zheltov, Teoriya vlasti (Moskva, Flinta: MPSI, 2008)

7. Internet 2017-2018 v mire $i v$ Rossii: statistika i trendy, https://www.web-canape.ru

8. I.A. Konovalova, Sacyyalogiya. Belaruskaya dumka 2, $92-96$ (2016)

9. Mediasfera Belarusi: sociologicheskij aspect (2015) http://iac.gov.by

10. V.I. Onoprienko, Naukovedenie: poisk sistemnyh idei (GP «Informacionnoanaliticheskoe agentstvo», Kyiv, 2008)

11. T.A. Poda, Osoblivosti komunikacii XXI st. i ii vplyv na svitovu politiku (Kyiv, 2012) https://er.nau.edu.ua/handle/NAU/17126

12. V.A. Reznichenko, Problemy programuvannya 4, 60-72 (2005)

13. I.P. Skyba, Visnyk Natsionalnoho aviatsiinoho universytetu. Seriia: Filosofiia. Kulturolohiia: Zbirnyk naukovykh prats 1(27), 83-89 (2018)

14. O.P. Skyba, Visnyk Natsionalnoho aviatsiinoho universytetu. Seriia: Filosofiia. Kulturolohiia: Zbirnyk naukovykh prats 1(27), 113-117 (2018)

15. O.M. Sidorkina, Visnyk Natsionalnoho aviatsiinoho universytetu. Seriia: Filosofiia. Kulturolohiia: Zbirnyk naukovykh prats 1(25), 120-123 (2017)

16. N.A. Chenbai, Visnyk Natsionalnoho aviatsiinoho universytetu. Seriia: Filosofiia. Kulturolohiia: Zbirnyk naukovykh prats. 1(27), 129-132 (2018)

17. T.O. Yaroshenko, Naukovi komunikacii XXI stolittya: elektronni resursy dlya nauki ta osvity Ukrainy. Naukovi praci. 52(39), 148-154 (2006)

18. M. Marcoccia, Language \& Intercultural Communication 12(4), 353-368 (2012)

19. J. Matusitz, Journal of Human Behavior in the Social Environment 24(7), 713-724 (2014)

20. J. Montepare, Journal of Nonverbal Behavior 38(4), 409-411 (2014)

21. S. Yildiz, Journal of Studies in International Education 13(1), 46-65 (2009) 